\title{
THE SOCIAL DISABILITY MODEL AND ITS IMPACT ON THEORY AND PRACTICE IN PSYCHOLOGY AND REHABILITATION'
}

\author{
Vanja NENADOVIĆ2, ${ }^{,}$, Dragana STANIMIROVIĆ ${ }^{*}$, Sanja DIMOSKI ${ }^{* *}$ \\ ${ }^{*}$ Institute for Experimental Phonetics and Speech Pathology \\ Life Activities Advancement Centre \\ ${ }^{* *}$ University of Belgrade \\ Faculty of Special Education and Rehabilitation
}

This paper represents a review of genesis and basic assertions of the social disability model (SDM) and its impact on theory and practice in psychology and rehabilitation. With its view on disability as a form of oppression, SDM is focused on changing society. The developmental pathway from the earliest radical forms of the SDM to the recent more neutral orientation is shown. The study then turns to the changes in psychological theory and practice. The contribution of critical psychology in the struggle for social change is described first. Afterwards, traditional psychology is criticized on several levels, with more contemporary views offered in the spirit of the new disability paradigm. These are shown as useful for assessment and intervention of disabled persons. The work is especially focused on psychological counselling, with a brief overview of theoretical aspects of counselling, compatible with the SDM and recommendations of different authors within this framework, concerning counselling practice in psychology and rehabilitation.

1 This paper is the result of the research project „Interdisciplinary research of verbal communication quality“ ON 178027 and E-logoped 32032, financed by the Ministry of Education, Science and Technological Development of the Republic of Serbia

2 E-mail: vilhi@sezampro.rs 
Specijalna edukacija i rehabilitacija (Beograd), Vol. 16, br. 4. 467-489, 2017.

Key words: social disability model, traditional psychology, critical psychology, psychological counselling, counselling in rehabilitation

\section{THE SOCIAL DISABILITY MODEL - ITS GENESIS AND BASIC ASSERTIONS}

The social disability model (SDM) appeared in the UK in the 1970s through the efforts of The Union of Physically Impaired Against Segregation (UPIAS), followed by Finkelstein, Barns and Oliver (Oliver, 1996) who laid its foundations at the academic level during the 1980s. In its greatest part, it represents a reaction to the existing biomedical disability approach. The new paradigm is a phrase used in literature to mark the transfer from the classical medical disability model (MDM) towards the SDM. In creating the new paradigm, the greatest focus has been on the environment and not the individual as is the case with the MDM. The SDM deals with all forms of exclusion of the disabled individual from physical barriers to attitudes and beliefs on disability. Its key goal is achievement of human rights for disabled people and it represents a significant part of disability policy in Great Britain and many countries all over the world today. With its view on disability as a form of oppression, this model is focused on changing society (Silvers, 2010; Thomas, 2004).

A number of concepts within the feminist school of thought, dealing with unequal distribution of power, are in accordance with the SDM. Building their theoretical approach on sexual inequality, they have developed concepts which can be used on other types on inequality such as age, sexual orientation, class, economic status and disability (Hammell, 2006). The role of environment is also explained in the feminist theory. For example, one of the examined topics is the environmental impact in cases of mental disorders. One of the main conclusions is that reactions of the individual diagnosed with a mental disorder to his or her unfavourable 
environmental factors or conditions of oppression have often been misinterpreted as pathology. Direct recommendations to clients are clearly listed, concerning ways of struggling with oppression in their environments. Thus, the environmental factor is viewed through its negative impact on the disabled person in both approaches.

The SDM points to unequal distribution of material goods, unequal power, and limited opportunities of disabled peoples' participation in everyday lives, compared to the nondisabled (Barnes \& Mercer, 2003). According to Finkelstein and Oliver, the essence of exclusion is based in capitalist economy (Lang, 2001). Social exclusion includes all relevant segments of society - economic, social, legal, cultural and political. Therefore, the focus of the new paradigm is treating social exclusion issues and avoiding the MDM's creation of victims. Disability cannot be burdened on the individual. It is an expression used for difficulties disabled individuals face in all segments of society. Minimising disability would enable distribution of equal rights and opportunities, as well as equal responsibilities faced by all members of society (Lutz \& Bowers, 2003).

In further elaboration of the SDM, it is necessary to differentiate between two key concepts relevant for disability theory and practice with the disabled: disability and impairment. While impairment is a functional limitation of the individual and is of physical, mental or sensory nature, disability is the loss or limitation of the opportunity to participate in normal life of the community due to physical or social barriers (Oliver, 1996). There is a dispute between authors concerning the position of impairment in their theorising, with more radical ones disregarding impairment in total. However, ignoring impairment will present a problem when experience of impairment is defined. In reality, loss of function, pain or physical limitation of movement can also have an effect of ridicule, stigmatisation and discrimination. Radical forms of the SDM overlook this segment. 
Specijalna edukacija i rehabilitacija (Beograd), Vol. 16, br. 4. 467-489, 2017.

The SDM described as such, has helped identification and development of political strategies, eliminating social barriers and promoting inclusion. It highlighted the demand for precise identification and analysis of social, political and economic factors which represent obstacles for the disabled individual, while also adding an element of ideology (Mulvany, 2000). In addition, the transition from the MM to the SDM has brought the disability community a certain amount of liberation and strength in their own rights, changing the dependence upon goodwill and charity (Sheakspeare \& Watson, 2001). The SDM has made this population more active and „visible" to the rest of the society (Tregaskis, 2004).

\section{EXPANDING THE SOCIAL DISABILITY MODEL}

After the first wave of radical materialism which achieved changes on the socio-political level, the next generation of authors was set on revising the existing SDM. They question two major issues. One is the Cartesian gap between impairment and disability, especially underscoring the body within the SDM (see Hammell, 2006 for a comprehensive review of the concept of the body), while the other is the issue of homogeneity of the population of the disabled (Lang, 2001).

The relation of disabled individuals with their body, limited to medicine and rehabilitation and at a distance from politics and political analysis represents a dualism within the SDM: the body and the impairment are placed within the domain of biomedicine and away from social analysis. The experience of an individual in some cases suffering everyday chronic pain has to be considered a significant part of the disability experience. Impairment and disability are different categories of a unique experience and have to be regarded as such. Some critics of the SDM have targeted another aspect of its reductionism: negation of the personal dimension or emotional level of functioning (see Crow, 1996 on personal experiences of pain and physical limitation). 
The early SDM, with its focus solely on the social environment, neglected body identity, personality and the potential for transformation. The influence of disability on psychological wellbeing and functioning of the individual is one of the most important facts to be established by the professionals within efficient practice. This is why it was relevant to expand the SDM and include subjective experience of disability. For instance, Scully, according to Silvers (2010) is of the opinion that marginalisation of disabled individuals cannot be resolved as either a theoretical or political issue, if we disregard the subjective experience. By highlighting the subjective experience, the authors are promoting an individualised approach to every disabled person, acknowledging their diverse experiences and exploring forms in which disability is „filtered“ through every person and their capacities.

Thomas (2004) elaborates on the relation between psycho-emotional wellbeing and the social environment, thus offering an expansion of the social concept of disability. Reeve (2004) also points to the need for extending the SDM to include psycho-emotional dimensions of disability. She describes Thomas' model which includes everyday experience of disabled individuals and the issue of their identity. This knowledge is significant for theory, as well as planned interventions. According to Reeve (2004), Thomas notes that members of the family or professionals can act as factors of disablism. Further, the psycho-emotional dimension can be analysed as a reaction to disablism found in iconography, cultural representations and interactions with others. Reeve examines oppression in two aspects - the public and the personal. Namely, the disability experience includes being in public. This experience can be marked with gazing, hostility or pity, or otherwise a condescending attitude. Therefore, everyday situations can be connected to certain emotional states such as shame, feeling of lesser value, etc.

Reeve (2004), thus presents the expanded definition of disability to include the socio-structural and emotional level. The first level includes physical barriers, as well as social 
processes and practices. The emotional level includes emotions of individuals facing these barriers (feeling of not belonging, inadequacy, etc.). Another group of feelings are those that are the consequence of interactions between disabled and nondisabled individuals. The second level includes internalisation of prejudice characterised by the dominant group. Low selfesteem can be an obstacle in creating deep and meaningful emotional relationships and, in extreme cases, can even lead to bullying or maltreatment. Reeve particularly pays attention to the issue of internalised oppression or the minority group's acceptance of negative attitudes held by the majority group. "This form of oppression is most effective when it is acting at the subconscious level, affecting the self-esteem of the individual in addition to shaping their thoughts and actions" (Marks, according to Reeve, 2004, p. 94).

As we have already pointed out, avoidance of impairment ignores a large part of the disabled individual's identity. According to Shakespeare and Watson (Shakespeare \& Watson, 2001), this has implications for the political dimension concerning forming of a group identity. Some individuals feel resistance in identifying with such a radical group. The development of a sense of collective identity can be difficult in real life. Based on data collected from a disabled members' group, Humphrey (2000) presents descriptions of individual disability experiences which show a feeling of exclusion for some forms of disability, compared to others. Those with non-visible types of disability felt unsure of themselves in the light of other, more visible ones, in the context of demanding their own rights as disabled people. Some participants in the project were uncertain in their use of the word „impaired“, which this particular group had discarded. This caused some members to re-examine their sense of belonging to the group. One of the SDM's controversies emerges here, in viewing the population of the disabled as a homogenous group (unified by the struggle against oppression), thereby ignoring the fine lines between each of the individual's experiences as had emerged in Humphrey' study. This is not the only study that has shown 
lack of desire of some disabled individuals to identify with the population of the disabled either in the political or medical sense (Shakespeare \& Watson, 2001).

In discussing identity formation in disabled persons, Murugami (2009) argues that a disabled person can create an identity independent of his or her impairment without losing a sense of self. She quotes Watson in a key point of defining self-identity not through diversity or labelling, but finding its own terms, within disability. In an example of true normalisation, the disabled person views herself or himself primarily as a person with disability as one of many aspects of identity. Murugami lists efforts that need to be taken at the environmental level, in order to create a milieu that fosters the development of self-identity and a positive self-concept.

According to Olkin (1999), every disabled individual has at some point experienced some form of discrimination, but each person has reacted differently to these experiences (APA, 2012). In other words, the individual gives a unique meaning to the disability experience, depending on the type of disability, social support and life demands. Also, the nature of the onset of disability is relevant in its influence on the psyche (whether the condition is chronic, whether the change is sudden or gradual,), as well as type of disability (whether it is progressive, etc.). However, there is a scant body of research focused on heterogeneity of personal experiences of disabled individuals based on factors such as age, gender, ethnicity, etc.

French (1994) highlights contribution of some factors such as: age of onset, visibility, how much it deviates from the normative model, existence of comorbid states. Some similar factors influencing the experience of disabled people were selected in the guidelines of the American Psychological Association published in (2012): level of social isolation, everyday difficulties, type of disability (not only the level of disability but also its social context: whether it is visible or not etc.). Thus, amongst factors to be estimated are those unique to all people: sex, age, culture, ethnicity, race, education, 
family, community, friends, colleagues, partners and identity. The structure of all these factors creates a unique life history of every person. The professional's role is to identify the fine interactions between the listed factors, existence of difficulties as seen by the client, and finally, to plan an efficient intervention. The APA guidelines usefully point to the role of psychologist in the exploration of opportunities and challenges of assistive technology in the light of individual personalities of people who use them, the ways it poses social barriers, but increases efficiency and reaching life goals.

In sum, the SDM has been expanded and revised in order to include the issue of experience, embodiment and a growing number of disability forms as well as the analysis of exclusion within contemporary culture. This is why the "social approach to disability" is a more adequate phrase today (Mulvany, 2000). This is an eclectic approach which maintains the SDM's starting principles (Stanimirović, 2006). Mulvany (2000) describes that a number of disputes between authors within the disability theory, is the relation between impairment, identity, disability and empowerment. These are important notices for professionals working with disabled individuals, since a professional approach needs to encompass complex relations between the described dimensions for valid and efficient planning and realisation of an intervention.

\section{CRITICAL PSYCHOLOGY AS PART OF THE STRUGGLE FOR SOCIAL CHANGE}

In its effort to use psychology in a more progressive way in social context, critical psychology has contributed to disability issues in accordance with the SDM. Building on critical (neo-marxist) theory, authors assumed that traditional psychological practice and its norms represented barriers towards social justice. They described and offered solutions for the so-called status quo of psychology. Psychology cannot be free of social and political context because it deals with human issues which by nature are mostly social. 
Critical psychology authors (with Klaus Holzkamp as one of its founders) claim that there is no such thing as a neutral position. In other words, every attitude, theory, or school of thought within psychology is derived from a certain system of values and so is each psychologist personality. Representatives of critical psychology have also criticized the methodology of psychology as a science, describing it as a positivistically oriented method derived from "tidy" laboratories, which needs to be implemented on less "tidy" issues of everyday life. They stress the need for more qualitative, interpretative and "softer" methods (see Fox \& Prilleltensky, 1997 for basic principles).

In the spirit of the SDM, the efforts of getting psychological practice closer to social justice can be achieved at a number of levels. In closer examination on how to achieve a social agenda within counselling practice, Prilleltensky and Prilleltensky (Prilleltensky \& Prilleltensky, 2003) have grouped human needs and values into three spheres of wellbeing and liberation: personal, relational or collective. Personal needs such as sense of mastery and control are promoted by values such as empowerment and self-determination. Relational needs such as support and affective bonds are based on values such as caring, compassion and valuing diversity. Collective needs like economic security, shelter and structural safety nets are met by values such as social justice, equality, emancipation, and economic security. There is no value comprehensive enough to include all human needs. Values have "synergic" qualities. Authors point to psychologists' inefficiency when focused solely on one level due to interdependence of these systems of values operating at the micro, meso and macro level. They maintain that relational and collective empowerment is needed in support of the personal level and vice versa. It is every professional's obligation to examine and identify the mood of the times in order to uncover the values that are missing. Another important step is using critiques of psychology and other fields.

Prilleltenskys' conclusions are applicable to all marginalised groups, but the paper uses illustrations derived from practice with disabled individuals. In sum, this socially 
oriented position is surely a challenge for psychology in all areas: education, practice, research, decision making and policy creation (Pledger, 2004). We can now single out crucial aspects for disability theory and practice: avoiding insularity of the profession through synergy of different values. On the level of theory, this approach is valuable because it merges the socio-cultural and psychological dimension within practice, thus making a connection between the value system, as a representative of a larger system, and human needs. Secondly, synergy of wellbeing and liberation calls upon direct association between practice with disability subjects and the SDM. This means that the roles of a psychologist as a healer and social agent, helping social participation, can be merged into one. Third, learning from existing criticism of psychology as well as criticism from outside psychology should incorporate views of marginalised groups towards the counselling profession.

Thus, critical psychology underlines the importance of the psychologists' participation in development of disability policy. It demands some revisions of traditional psychology.

\section{PSYCHOLOGY UNDER CRITICISM: WHAT NEEDS TO BE REVISED?}

A number of authors working on the role of psychology in disability theory and practice have highlighted the need for revising several levels within psychology (Gill, Kewman \& Brannon, 2003; Lutz \& Bowers, 2003; Smart \& Smart, 2006; Tang \& Lee, 2010). We can summarize their remarks into three categories.

The first one is the academic level, including expanding academic knowledge on disabled individuals (Mpofu \& Bishop, 2006; Olkin \& Pledger, 2003; Singh et al., 2010; Vasquez et al., 2006). For example, psychologists need to increase their knowledge in the area of mobility or sensory, neurological and communication disability. This is the only way for psychologists to fully develop relevant methods of intervention 
and clearly identify issues which are outside the domain of psychology (Pledger, 2003). Gill, Kewman and Brannon (Gill, Kewman \& Brannon, 2003) have also pinpointed the need for expansion of education to include perspectives from sociology, anthropology, social sciences and social policy which are relevant for disability. This will enable psychologists to be more competent with clients (consumers) in creating policies and services focused on overcoming the gap between policy creators and disabled individuals.

The second level where revision is needed is the psychologist's own systems of values and beliefs. A number of authors have acknowledged the danger of professionals themselves becoming factors of disablism (Reeve, 2000; Smart $\&$ Smart, 2006). In her discussion on the reasons for this, Reeve elaborates on disabled individuals as professionals: "disability is not present in the room as an issue the way race and gender are" (Reeve, 2000, p. 674). In other words, there are a few psychologists which are disabled themselves. This means that there are not many views taking on a position "from within".

The third level includes removing barriers within the psychological and rehabilitation practice. These are environmental accommodations and inclusion of disability related issues in assessment and intervention (APA, 2012). The professional's intervention plan needs to consider a complex network of biological, psychological, social, environmental, economic, legal and political factors of functioning in order to reflect the new paradigm, as the new conceptual framework (Olkin \& Pledger, 2003). Both intervention and research need to be collaborative.

Olkin and Pledger (2003) have listed characteristics concerning psychological research and practice which mark the new paradigm:

- based on the SDM,

- shifts to a societal and systemic perspective,

- takes on a life span approach, 
Specijalna edukacija i rehabilitacija (Beograd), Vol. 16, br. 4. 467-489, 2017.

- uses the concept of "response to" disability as a fluid process,

- promotes health and resilience,

- usually focused on chronic phases of disability,

- more likely to be in community settings,

- values disability culture and history,

- includes those being researched in the research process,

- sees the major problems of disability as social, political, economic and legal,

- is grounded in the belief that disabled individuals are denied their civil rights,

- seeks remedies in public policies, legislation and systemic programmatic changes,

- is usually not just about disabled individuals, but by disabled individuals.

Unlike other areas of psychology, counselling would be less deserving of criticism from the SDM's position. As some authors have pointed out, the history of development of psychological counselling, including its essential values has a social justice framework, as well as a strong environmental orientation in achieving the wellbeing of its clients (Goodman et al., 2004). However, some aspects of counselling have been revised in order to fit into the new paradigm.

When discussing the process of change within counselling and psychotherapy, the SDM is set on criticising psychology's fundamental position of achieving psychological change. Amongst the most important theoretical touchstones is the theory of loss and phases of acceptance of one's own impairment, and gradual adaptation to impairment. These theories imply that impairment is a personal and life tragedy of an individual which is psychologically devastating resulting in sorrow as the only possible reaction (Oliver, 1996). Pathologization, negativity, focus on impairment are all characteristics of the MDM. Isolating a solitary reaction to 
impairment has a deep personal connotation, thus ignoring the reactions of the environment (such as disregarding emotional reactions to a disrupting environment, for example). According to Reeve (2000), if professionals can clearly differentiate between impairment and disability, they will not need to call on theory of loss, nor acknowledge its value in practice. Today's growing opinion is that interaction of disability and environment has a higher effect on the individual's own experience, than phases of loss such as shock, depression, anger, which have never acquired a sound empirical basis (Olkin, 1999). Traditional psychology overlooks an important fact: not all disabled individuals need counselling (however, theory of loss calls on the mechanism of denial if a person refuses counselling!).

Revising one's own attitudes on disability also needs to include empirical findings which can be considered a paradox at first glance, the feeling of satisfaction of a disabled individual. Authors within the 'strong' SDM claim that disabled individuals have achieved their rights without help of professionals and in some cases, in spite of professionals (Prilleltensky \& Prilleltensky, 2003). Are we capable to decide who really needs psychological counselling? According to Albrecht and Devlieger (1999), Weinberg (1988) gives examples from her empirical studies on disabled individuals who sense a deep satisfaction with who they are, or list their life goals which are achieved in spite or even due to disability. These reports are in opposition to society's view of disability as a continuing tragedy (Albrecht \& Devlieger, 1999).

Counselling also needs to address physical and economic barriers. The SDM treats the situation of psychological counselling as one with tough physical barriers for disabled individuals (they offer a solution of telephone counselling and home visits). Unavailability of these services can also be ascribed to low financial potential of disabled individuals, because of lower job opportunities (Pelletier, Rogers \& Dellario, 1985). 
Specijalna edukacija i rehabilitacija (Beograd), Vol. 16, br. 4. 467-489, 2017.

The counselling theory and practice has developed within a number of psychological schools. Different authors ask questions regarding the theoretical aspects of counselling compatible with the SDM and offer recommendations within this framework, concerning counselling practice.

\section{PSYCHOLOGICAL COUNSELLING: IS IT COMPATIBLE WITH THE SOCIAL DISABILITY MODEL?}

Traditionally, psychological counselling grew from roots laid down by the early psychoanalysts who were scientifically trained in positivist thinking within the framework of the MDM. Behaviourists and cognitive behaviourists came later, also within the positivist tradition (Griffiths, 2002). The humanistic approach started in 1950s as an opposite to the existing medical approach, emphasizing the human tendency towards personal growth, but it was not considered scientific (Mindoljević Drakulić, 2012). Besides, none of the three schools considered the client's social context in genesis of the problem as well as its solving. Truly, only feminist and systems approach fit into psychological theories sensitive to environmental influences and focused on changes at this level.

On the other hand, counselling within the SDM framework guides us towards client-centred counselling which is more neutral than psychodynamic and behavioural approaches. In other words, client centred approach offers unconditional acceptance of the client, trust in his independent decision-making and constructiveness. The focus is on the person, not the problem. The fundamental attitude is forming a relationship of mutual trust. These attitudes leave no room for a directive counsellor and create a balance in the clientcounsellor relationship, thus distancing from the MDM upon which numerous approaches are based. Client-centred approach trusts the client to govern his or her own life, which is the SDM's attitude as well. Therefore, some authors point to 
client-centred model as an optimal choice for disabled clients (Lenny, 1993).

Reeve (2004) claims that disability counselling needs to stimulate the process of positive self-identification and empowerment towards making changes in their own lives. Some authors offer forms of cognitive-behavioural counselling model and solution-focused model, because these are based on the positive, on strengths and possibilities and active participation of the client. In this case, the client is considered an expert on the subject of his own life, while the process of counselling is based on collaboration. However, these approaches avoid assuming how the client feels. Reeve (2000) offers transcultural counselling which has been developed over the last two decades, raising awareness on cultural differences between clients and counsellor.

Transcultural counselling takes into consideration the reality of discrimination and prejudice in the life of the client. Unlike client-centred approach, here, there is constant demand on revising one's own attitudes and prejudice and the danger of holding simplified attitudes when facing clients from culturally different backgrounds. Another important aspect of the client-counsellor relationship taken from feminist and multicultural theory is concerned with the distribution of power. Professionals need to take caution in avoiding the role of saviour from oppression. The professional needs to act as a resource or partner, not the expert. Reeve (2000) emphasizes the need for disability equality training as well as application of some concepts concerning oppression, imported from transcultural counselling. A user-friendly approach is the most optimal selection in this context since it has a strong political and social foundation. Within counselling of parents of children with chronic illnesses or disabilities, the work of Hilton Davis is notable as one of the approaches which are less stigmatising, community-based, focused on meeting the needs of families which would not receive help otherwise (deprived city areas). Here, together with the strong social component, a creation of a "partnership" with the parent is strongly accented, 
lessening the authority of professional in problem-solving (Davis \& Spurr, 1993).

In the same vein are recommendations of the feminist theory: constant awareness on the hierarchy of power and domination as well as the need for controlling oppression attitudes (Goodman et al., 2004). Equal distribution of power is not only collaboration during the process of counselling, but also flexibility in changing roles during the process. In this context, another useful consideration is that of awareness of privilege (Israel, 2012). Israel offers an even wider framework unveiling difficulties of identifying situations of oppression when we are not aware of its opposite, privilege. This opens up an area not only for individual but also group empowerment. According to Rappaport, one of the founders of community psychology, giving voice to oppressed communities means helping communities develop collective narratives on their own lives, issues and goals. This approach to professionals' help and support overcomes the traditional concepts of counselling theory and practice. Pledger (2003) points to the need for identifying oppression within counselling practice and offers the SDM model as a key framework for counselling today.

By integrating theory, research and practice, the professional's end-goal is achieving an optimal state, relieving suffering, helping adaptation, resolving crises and enhancing skills for functionalliving. Counselling is focused on emotional, social, professional, educational, health, developmental and organisational problems of individuals. Some authors stress the need for psychological services within the health care system in rehabilitation processes (Griffiths, 2002; Havelka, Pačić-Turk \& Sever, 2004; See \& Kamnetz, 2004). Griffiths explains: "Disabled people have many of the same problems as able-bodied people, problems in relationships, parenting, work, abuse and a range of other life problems. However, many of these problems are exacerbated by chronic illness and disability, especially when additional difficulties are experienced as a result of environment and societal attitudes" (Griffiths, 2002, pp.19-20). During her practice in the field of rehabilitation 
counselling, she gradually found areas which seemed to meet current concerns on placements: what to do when a patient has just been told some bad news by the doctor and does not want to enter his or her treatment programme; how to cope with aggression from relatives; problems of communication in the multidisciplinary team, etc.

In sum, the SDM based approach in psychological theory, research and practice is holistic, environmentalist, with a wider developmental context and a higher social responsibility. The counselling process includes active participation of both sides (especially in planning and creating counselling goals). Viewing disability as a social construct helps the professional in empowering his client. The process of developing skills necessary for advocating one's rights influences selfdetermination. The individuals' struggle for economic, political and social rights can bring a sense of wellbeing and empowerment as psychological benefits of the process. In addition to being focused on individuality of the disabled person's experience, the counsellor needs to be focused on collective problems of this population, as accented by the SDM.

\section{CONCLUSION}

Forming the psychologist's and rehabilitator's identity in the area of disability theory and practice is a complex process. It includes raising awareness and acting on a number of levels, as we have tried to present in this article. We have explored the SDM's influence on changes within psychology and rehabilitation concerning some minority groups, but foremost disabled individuals. Possession of specific knowledge and experience, the disabled individuals' emancipation in the counselling room can lead not only to efficient, but also ethical counselling. In a more radical, but necessary line of thought, we have described the psychologists exiting their counselling rooms and entering community, in order to establish themselves as factors of influence on decision making 
and policy creation. The development of the SDM from the "strong" position to today's more neutral position of "social approach" shows that this model had different uses in different times for the population of disabled individuals. The Republic of Serbia signed the Convention on Disabled Persons' Rights in 2007 which was ratified in 2009. Article 8 presents defined steps in awareness-raising, which is an important legislative step in this context. After achieving crucial steps towards emancipation, it was necessary to revise the theory so it could be of use, amongst other things, to those disciplines that claim to serve disabled people.

The tradition of psychological counselling has quite an open framework, encompassing an affirmative approach to problems and a neutral position concerning the client's goals, activating the client in his tendencies to achieve wellbeing. This is all compatible with the new paradigm. However, professionals still lack sufficient models of counselling modified for the population of the disabled. These models need to be tested and monitored in practice, in cooperation with clients themselves. Also, this field, probably more than some other, should lay a firm foundation on inter-professional cooperation. Clinical practice shows us that valid changes can only be made if there is continuing communication in the decision making chain.

\section{REFERENCES}

1. Albrecht, G. L. \& Devlieger, P. J. (1999). The disability paradox: High quality of life against all odds. Social Science \& Medicine, 48, 977-988.

2. American Psychological Association. (2012). Guidelines for assessment of and intervention with persons with disabilities. The American Psychologist, 67(1), 43-62. doi: 10.1037/a0025892

3. Barnes, C. \& Mercer, G. (2003). Disability. Cambridge: The Polity Press. 
4. Crow, L. (1996). Including all our lives: Renewing the social model of disability. In J. Morris (Ed.), Encounters with strangers: Feminism and disability (pp. 206-226). London: Women's Press.

5. Davis, H. \& Spurr, P. (1993). Parent councelling: An evaluation of a community child mental health service. Journal of Child Psychology and Psychiatry, 39, 365-375.

6. French, S. (1994). The disabled role. In S. French (ed.), On equal terms: Working with disabled people. Oxford: ButterworthHeinemann.

7. Fox, D. \& Prilleltensky, I. (1997). Critical psychology: an introduction. London: Sage Publications.

8. Gill, C. J., Kewman, D. G., \& Brannon, R. W. (2003). Transforming psychological practice and society: Policies that reflect the new paradigm. American Psychologist, 58, 305-312. doi: 10.1037/0003066X.58.4.305

9. Goodman, A. L., Liang, B., Helms, J. E., Latta, R. E., Sparks, E., \& Weintraub, S. R. (2004). Training Counselling Psychologists as Social Justice Agents: Feminist and Multicultural Principles in Action. The Counselling Psychologist, 32(6), 793-837. doi. org $/ 10.1177 / 0011000004268802$

10. Griffiths, P. (2002). Counselling in rehabilitation - the UK story. In K. Etherington (Ed.) Rehabilitation counselling in physical and mental health (pp. 27-46). London \& New York: Jessica Kingsley publishers.

11. Hammell, K. W. (2006). Perspectives on Disability \& Rehabilitation: Contesting Assumptions; Challenging Practice. Edinborough, UK: Churchill Livingstone Elsevier

12. Havelka, M., Pačić-Turk, Lj. \& Sever, T. (2004). Zdravstvena psihologija u Hrvatskoj dvadesetak godina poslije. Društvena istraživanja, 13(3), 465-486.

13. Humphrey, J. (2000). Researching disability politics, or, some problems with the social model in practice. Disability and Society, 15(1), 63-85. doi: 10.1080/09687590025775

14. Israel, T. (2012).2011 Society of counselling psychologypresidential address: exploring privilege in counselling psychology: Shifting 
Specijalna edukacija i rehabilitacija (Beograd), Vol. 16, br. 4. 467-489, 2017.

the lens. The Counselling Psychologist, 40(1), 158-180. doi: $10.1177 / 0011000011426297$

15. Lang, R. (2001). The development and critique of the social model of disability. University of East Anglia. Retrieved March 29, 2015 from http://www.ucl.ac.uk/lc-ccr/lccstaff/raymond-lang

16. Lenny, J. (1993). Do disabled people need counselling? In J. Swain, V. Finkelstein, S. French, \& M. Oliver (Eds.), Disabling barriers - Enabling environments (pp. 233-240). London: Sage and Open University Press.

17. Lutz, B. J. \& Bowers, B. J. (2003). Understanding how disability is defined and conceptualized in the literature. Rehabilitation Nursing, 28(3), 74-78. doi: 10.1002/j.2048-7940.2003.tb02037.x

18. Mindoljević Drakulić, A. (2012). A phenomenological perspective on subjective well-being: From myth to science. Psychiatria Danubina, 24, 31-37.

19. Mpofu, E. \& Bishop, M. (2006). Value Change and Adjustment to Disability: Implications for Rehabilitation Education, Practice, and Research. Rehabilitation Education, 20(3), 147-161. doi. org/10.1891/088970106805074412

20. Mulvany, J. (2000). Disability, impairment or illness? The relevance of the social model of disability to the study of mental disorder. Sociology of Health and Illness, 22(5), 582-601. doi: 10.1111/14679566.00221

21. Murugami, M. W. (2009). Disability and Identity. Disability Studies Quarterly, 29(4), Retrieved July 12, 2015 from http://dsqsds.org/article/view/979/1173

22. Oliver, M. (1996). Understanding disability: from theory to practice. London: Macmillan.

23. Olkin, R. (1999). What psychotherapists should know about disability. New York: Guilford Press.

24. Olkin, R., \& Pledger, C. (2003). Can disability studies and psychology join hands? American Psychologist, 58(4), 296-304. doi:10.1037/0003-066x.58.4.296

25. Pelletier, J. R., Rogers, E. S., \& Dellario, D. J. (1985). Barriers to the provision of mental health services to individuals with severe 
physical disability. Journal of Counselling Psychology, 32(3), 422430. doi: 10.1037/0022-0167.32.3.422

26. Pledger, C. (2003). Discourse on disability and rehabilitation issues: Opportunities for psychology. American Psychologist, 58(4), 279-284. doi.org/10.1037/0003-066X.58.4.279

27. Pledger, C. (2004). Disability paradigm shift. American Psychologist, 59(4), 275-276. doi: 10.1037/0003-066x.59.4.275

28. Prilleltensky, I. \& Prilleltensky, O. (2003). Synergies for wellness and liberation in counselling psychology. The Counselling Psychologist, 31(3), 273-281. doi: 10.1177/0011000003031003002

29. Reeve, D. (2000). Oppression in the counselling room. Disability and Society, 15(4), 669-682. doi: 10.1080/09687590050058242

30. Reeve, D. (2004). Psycho-emotional dimensions of disability and the social model. In C. Barnes \& G. Mercer (Eds.), Implementing the social model of disability: Theory and research (pp. 32-47). Leeds: The Disability Press.

31. See, J. \& Kamnetz, B. (2004). Person-centred counselling in rehabilitation professions. In N. Berven \& K. Thomas (Eds.), Counselling theories and techniques (pp. 76-97). Springer Publishing Company.

32. Shakespeare, T. \& Watson, N. (2001). The social model of disability: An outdated ideology? Research in Social Science and Disability, 2, 9-28. doi: 10.1016/s1479-3547(01)80018-x

33. Silvers, A. (2010). An essay on modelling: The social model of disability. In D.C. Ralston \& C. Ho (Eds.), Philosophical reflections on disability (pp. 19-37). Springer Science /Business Media B.V.

34. Singh, A., Hofsess, C. D., Boyer, E. M., Kwong, A. Lau, A. S. M., McLain, M., \& Haggins, K. L. (2010). Social justice and counselling psychology: Listening to the voices of doctoral trainees. The Counselling Psychologist, 38(6), 766-795. doi: 10.1177/0011000010362559

35. Smart, J. F. \& Smart, D. W. (2006). Models of disability: Implications for the counselling profession. Journal of Counselling \& Development, 84, 29-40. doi: 10.1002/j.1556-6678.2006. tb00377.x 
Specijalna edukacija i rehabilitacija (Beograd), Vol. 16, br. 4. 467-489, 2017.

36. Stanimirović, D. (2006). Toward more complete social inclusion of people with visual impairment. In: 6th international conference "Living together", Varaždin, pp. 143-150.

37. Tang, J. \& Lee, T. (2010). Transforming role of rehabilitation psychologists: New paradigm, challenges and directions. Chinese Journal of Rehabilitation Medicine, 25(4), 293-300. doi 10.3969/j. issn.1001-1242.2010.04.001

38. Thomas, C. (2004). Developing the social relational in the social model of disability: A theoretical agenda. In C. Barnes \& G. Mercer (Eds.), Implementing the social model of disability: Theory and research (pp. 32-47). Leeds: The Disability Press.

39. Tregaskis, C. (2004). Constructions of disability. Researching the interface: Theories on the construction of disability. London and New York: Routledge Taylor \& Francis Group.

40. Vasquez, M. J., Lott, B., García-Vázquez, E., Grant, S. K., Iwamasa, G. Y., Molina, L. E., ... \& Vestal-Dowdy, E. (2006). Personal reflections: Barriers and strategies in increasing diversity in psychology. American Psychologist, 61(2), 157-172. http://dx.doi. org/10.1037/0003-066X.61.2.157

41. Weinberg, N.(1988). Another perspective: Attitudes of people with disabilities. In H.E. Yuker, (Ed.), Attitudes Toward Persons with Disabilities (pp. 141-153). Springer, New York. 


\title{
SOCIJALNI MODEL OMETENOSTI I NJEGOV UTICAJ NA TEORIJU I PRAKSU U PSIHOLOGIJI I REHABILITACIJI
}

\author{
Vanja Nenadović*, Dragana Stanimirović ${ }^{* *}$, Sanja Dimoski** \\ "Institut za eksperimentalnu fonetiku i patologiju govora \\ Centar za unapređenje životnih aktivnosti \\ ${ }^{*}$ Univerzitet u Beogradu - Fakultet za specijalnu edukaciju i rehabilitaciju
}

\section{Sažetak}

Ova studija predstavlja prikaz razvoja socijalnog modela ometenosti (SMO), njegove osnovne pretpostavke, kao i uticaj na teoriju i praksu u psihologiji i rehabilitaciji. Posmatrajući ometenost kao formu ugnjetavanja, SMO je fokusiran na podsticanje društvenih promena. Prikazan je razvojni put od najranijih radikalnih oblika SMO do neutralnije socijalne orijentacije. Zatim su predstavljene promene u psihološkoj teoriji i praksi. Opisan je doprinos kritičke psihologije $\mathrm{u}$ borbi za socijalne promene. Tradicionalna psihologija je kritikovana na više nivoa i ponuđeno je nekoliko savremenih shvatanja $u$ duhu nove paradigme ometenosti. Diskusija je dalje usmerena na savremene pristupe, bazirane na težnji za socijalnim promenama, a koji mogu biti od koristi za procenu i intervencije kod osoba s ometenošću. Poseban prostor je posvećen psihološkom savetovanju, s kratkim osvrtom na teorijske aspekte savetovanja koji su kompatibilni sa SMO, kao i preporukama različitih autora unutar SMO, u vezi s praksom savetovanja u psihologiji i rehabilitaciji.

Ključne reči: socijalni model ometenosti, tradicionalna psihologija, kritička psihologija, psihološko savetovanje, savetovanje u rehabilitaciji

Primljeno: 05.08.2017.

Prihvaćeno: 10.11.2017. 